\title{
Laporan Literatur Review
}

\author{
Oleh \\ ( Rere Nugraha Akbari ) \\ Program Studi Pendidikan IPS FKIP ULM
}

NIM

$(1910111210015)$

\section{Buku yang di review}

Susanto, H., \& Akmal, H. (2019). Media Pembelajaran Sejarah Era Teknologi Informasi (Konsep Dasar, Prinsip Aplikatif, dan Perancangannya).

\section{Ringkasan isi bab}

Pada bab I dijelaskan, Media adalah alat atau perantara, dalam hal belajar dan pembelajaran, media memiliki peran penting, karenanya dapat merangsang para peserta didik untuk fokus terhadap apa yang dijelaskan dan gemar. Sedangkan pembelajaran adalah suatu proses agar mencapai titik paham dan mengerti. Dengan kata lain Media Pembelajaran memiliki arti sebuah pesan yang dibawa untuk melancarkan kegiatan belajar dan pembelajaran sesuai dengan tujuan dalam perencanaan belajar. Hal demikian dilakukan agar para penerima pelajaran mampu dengan hikmat mengikuti pembelajaran yang sedang berlangsung.

Media pembelajaran juga mampu membantu guru dalam menyelesaikan hambatanhambatan belajar. Hambatan-hambatan yang dimaksud adalah guru terkesan usang, klasik dan monoton dalam memberikan ilmu, sehingga terjadi penyimpangan-penyimpangan lainnya, seperti kesalahpahaman makna, lalu kurangnya rangsangan bagi para peserta didik, sehingga mereka lebih memilih untuk tidak mengikuti pelajaran karena mereka tidak menemukan ketertarikan dari apa yang telah ditawarkan guru dan berakibat pada minimnya respon di akhir pembelajaran jauh dari apa yang dicita-citakan dalam perencanaan pembelajaran. 
Pada proses pembelajaran, hal yang paling mendasari terciptanya pembelajaran yang berhasil adalah sumber belajar, dengan mempertimbangkan segala aspek antar sudut pandang guru dengan para peserta didik, guru diharapkan menemukan sumber belajar yang mampu dan menarik perhatian para murid untuk mengikuti pelajaran dengan serius. Namun dalam prinsip belajar dan pembelajaran, guru memang memegang peranan, namun ada peran besar yang terkadang dilupakan, yakni prinsip keinginan belajar dari diri sendiri/prinsip individu. Individu tersebut memegang peran besar, kemana akan membawa dirinya melangkah. Pembelajaran sendiri adalah sebuah komunikasi dua arah antara guru dengan murid. Dengan memperhatikan sumber belajar yang relevan, maka proses pembelajaran akan sampai sebagaimana yang telah ditujukan.

Dikemajuan zaman seperti saat ini, media pembelajaran berkembang pesat, tidak hanya bergantung pada buku-buku, namun banyak hal yang hadir disekeliling kita dapat dijadikan sebagai suatu media pembelajaran. Media sendiri terbagi menjadi tujuh kelompok, kelompok pertama terdiri atas grafis, bahan cetak dan gambar diam, kedua yakni media proyeksi diam, kelompok tiga, audio, keempat ada media audio ditambah media visual diam, kelima yaitu gambar hidup(film), keenam televisi dan ketujuh adalah multimedia, pengertian multimedia merujuk pada berbagai bahan ajar yang membentuk satu unit terpadu, yang dikombinasikan dalam bentuk modul.

Media pembelajaran sejarah, di era kemajuan zaman saat ini, banyak jenisnya, dimulai pada media sejarah non elektronik, media pembelajaran real object, dan berbasis elektronik. Ditemukannya gadget tentunya berperan besar dalam membantu kegiatan belajar mengajar, gadget secara tidak langsung membantu para peserta didik untuk belajar sendiri, ditambah kemajuan teknologi informasi yang semakin luas skala dan jangkauannya, seharusnya peserta didik lebih bijak dalam memanfaatkan gadget, memaknainya dan mengerti tujuan, hal itu lah yang berperan penting bagi proses pembelajaran.

Pada bab II dijelaskan, bahwa peserta didik membutuhkan media pembelajaran yang lebih dari sekedar power point. Power point hanya berisi tulisan, kemudian guru ceramah,memberikan pertanyaan kejutan, hal tersebut dikenal sebagai proses pemberian ilmu secara klasik. Dan menjadikan peserta didik tidak gemar akan mata pelajaran tersebut. Dampak nya adalah minim respon dari peserta didik, karena mereka merasa lelah mendengar gurunya berbicara, ditambah lagi kemampuan masing-masing individu dalam menerima pelajaran. Maka dari itu memahami prinsip belajar dan paham makna yang terdapat di tiap 
butir-butir prinsip menghasilkan tujuan yang diinginkan. Penentuan media pembelajaran dan sumber belajar juga terdapat pada rumusan kurikulum yang dibentuk, sehingga dalam hal tersebut, kompetensi dan tujuan pembelajaran menjadi pertimbangan utama dalam menentukan media yang akan digunakan. Keberhasilan proses pembelajaran bergantung pada penggunaan sumber dan media pembelajaran yang sesuai.

Dalam pembelajaran sejarah, ditemukan guru kebingungan dalam menentukan media yang sesuai, maka dari itu seorang guru harus mempertimbangkan beberapa prinsip acuan untuk pengoptimalan pembelajaran, antara lain efektifitas (guru harus mampu mengusahakan agar media pembelajaran yang diperlukan membentuk kompetensi secara optimal dapat digunakan sebagai media pembelajaran, Relevansi (kesesuaian media pembelajaran yang digunakan dengan tujuan, karateristik materi pelajaran, potensi dan perkembangan peserta didik, serta dengan waktu yang tersedia, efisiensi (Pemilihan media pembelajaran tersebut harus dipastikan, jika pemilihannya murah dan tidak banyak memakan biaya), dan kontekstual (pemilihan dan penggunaan media pembelajaran harus mengedepankan aspek lingkungan sosial dan budaya peserta didik).

Pada bab ini juga terdapat dampak dari kemajuan zaman bagi pembelajaran sejarah, dengan melihat konteks kekinian, media pembelajaran sejarah harus relevan dan berdasarkan pendekatan saintifik yang dikembangkan kurikulum. Maka dari itu untuk mengembangkan motivasi belajar, media menjadi satu-satunya acuan, sejarah adalah ilmu masa lalu, dan bersifat abstrak, karena yang ada di zaman sekarang atau sekeliling kita telah banyak dampak dari terjadinya peristiwa di masa lampau. dengan kemajuan teknologi, media mampu menjelaskan dan menampilkan tahap-tahap sejarah melalui film grafik, mengamati candi borobudur dengan skala di dalam kelas, dan lain sebagainya. Jenis media pendidikan sendiri, ada yang berada di sekolah dan ada yang berada di lingkungan sekitar.

Pada bab III dijelaskan, dengan ketersediaan sumber daya yang ada di sekeliling kita, sudah seyogyanya kita mampu menciptakan suatu loncatan besar bagi media pembelajaran sejarah, dengan menciptakan wadah untuk menampung media pembelajaran sejarah, agar terciptanya tujuan pembelajaran yang hikmat, damai dan tentram. Pembuatan media tersebut beracu pada kompetensi, yang kemudian ditinjau sumber belajar apa yang dibutuhkan dan media seperti apa yang melengkapi. Cara merancang media pembelajaran, dengan memperhitungkan segala aspek dan melihat ketersediaan, komponen yang harus diperhatikan 
adalah cakupan kompetensi, kedalaman materi, klasifikasi pengetahuan yang disampingkan, dan ketersediaan informasi pendukung.

\section{Media digital untuk pembelajaran era pandemi Covid-19}

Dalam kondisi wabah virus corona di Indonesia, pemerintah pusat meliburkan kegiatan pembelajaran luring di kampus, digantikan dengan pelajaran daring . media pembelajaran yang paling sering digunakan adalah zoom, google meet, simari $e$-learning.

Selain ketiga media di atas, menurut pendapat pribadi hal yang paling membantu dalam memahami materi yang sebelumnya telah dipaparkan, adalah whatsapp, dengan whatsapp mampu memudahkan diskusi tentang materi, tugas dan lain sebagainya.

Ditengah kemajuan teknologi informasi yang berkembang pesat, sayangnya belum merata kekuatan jaringan, sehingga bagi para mahasiswa/i yang berada di daerah yang jauh, sulit sekali terjangkau jaringan atau sinyal yang memadai, sehingga menganggu proses penerimaan materi dari dosen.

\section{Simpulan}

Dengan kemajuan bidang teknologi informasi, tentunya mempermudah segala kegiatan yang dilakukan, mempersingkat dan lebih terarah. Dengan kemajuan teknologi informasi, diharapkan komunikasi pembelajaran yang terjadi antar guru dan peserta didik tidak mengalami penyimpangan-penyimpangan. Sehingga diharapkan media pembelajaran sejarah yang ditawarkan mampu merangsang kreatifitas, ketertarikan para peserta didik.

\section{Referensi}

Susanto, Heri \& Akmal, Helmi. 2019. Media Pembelajaran Sejarah Era Teknologi Informasi (Konsep Dasar, Prinsip Aplikatif, dan Perancangannya). Banjarmasin: Program Studi Pendidikan Sejarah Fakultas Keguruan dan Ilmu Pendidikan Universitas Lambung Mangkurat. 